Original article

\title{
PATTERN OF PESTE DES PETITS RUMINANTS (PPR) DISTRIBUTION IN GHANA (2005-2013)
}

\author{
R. D. FOLITSE ${ }^{1}$, E. AMEMOR ${ }^{2}$, E. NYARKU REJOICE ${ }^{3}$, \\ B. O. EMIKPE ${ }^{1} \&$ W. TASIAME ${ }^{4}$ \\ ${ }^{1}$ Department of Pathobiology; ${ }^{2}$ Department of Clinical Studies; \\ ${ }^{3}$ School of Veterinary Medicine; ${ }^{4}$ Department of Public Health; Kwame \\ Nkrumah University of Science and Technology, Kumasi, Ghana
}

\section{Summary}

Folitse, R. D., E. Amemor, E. Nyarku Rejoice, B. O. Emikpe \& W. Tasiame, 2017. Pattern of peste des petits ruminants (PPR) distribution in Ghana (2005-2013). Bulg. J. Vet. Med., 20, No 1, 51-57.

Peste des petits ruminants (PPR) is one of the most devastating diseases that limit small ruminant industry in Ghana and causes substantial economic losses to small ruminant farmers. However, there is lack of documented evidence on the distribution of the disease across the various regions in the country. A retrospective epidemiological study was therefore conducted to investigate the pattern, distribution and prevalence of PPR disease in Ghana. The study also investigated the impact of vaccination on PPR burden using descriptive epidemiological analysis. Data on PPR outbreaks from 2005 to 2013 as well as vaccination records from the Veterinary Services Directorate in Ghana and from the International Office of Epizootics (OIE) were collated and used for this study. Results from the study indicated that PPR was endemic in Ghana, at a prevalence level of $6.84 \%$ per 1,000 population. All ten regions reported PPR outbreaks with Western region reporting the highest, followed by Eastern and Central regions. PPR occurred in both seasons, but mostly in the dry season. Vaccination programmes covered all the ten regions in Ghana. The lowest number of vaccinated animals and highest number of outbreaks were registered in the Western region, while Volta region had the highest number of vaccinated animals and lowest number of outbreaks. In conclusion, PPR disease is endemic in Ghana with highest outbreaks occurring at the peak of the dry season (January to March) and the onset of the rainy season (second quarter of the year). Vaccination had a positive impact on the occurrence of PPR in Ghana.

Key words: distribution, Ghana, pattern, PPR, retrospective

\section{INTRODUCTION}

Peste des petits ruminants (PPR) is a highly contagious and infectious viral disease of domestic and wild small ruminants (Anonymous, 1999; Munir, 2014) with symptoms similar to Rinderpest, characterised by fever, erosive stomatitis, oculonasal discharges, diarrhoea and pneumonia (ILRI, 1980; Scott, 1981; Anonymous, 2011). The disease is caused by the PPR virus (PPRV) which belongs to the 
family Paramyxoviridae, genus Morbillivirus (Bailey et al., 2005).

The economic importance of PPR is principally due to its highly contagious nature, with a case fatality rate reaching $100 \%$. This is of particular concern for small holder rural farms where small ruminants are reared as the sole source of income (Emikpe \& Akpavie, 2011). PPR is currently considered as one of the main transboundary animal diseases (TAD) that hampers livestock production in many developing countries particularly in West Africa and South Asia, notifiable to the Office of International Epizootics. In all, $62.5 \%$ of the global domestic small ruminant population is at risk of PPR (Anonymous, 2013a). The estimated loss is USD 1.45 to 2.1 billion every year (OIE, 2015).

In Ghana, agriculture contributes to about $22.6 \%$ of the gross domestic product (GDP). Livestock plays a very important role in the national economy because of its contribution to the national GDP (about 5.3\%) indicating that livestock is indispensable to the optimisation of the Ghanaian farming and livelihood systems (Ghana Statistical Service, 2013).

In Ghana, small ruminants play a very important role in the livelihood of farmers, especially the rural poor (Tuah et al., 1989). Notwithstanding that, Ghana still depends largely on imported livestock products to meet the growing demand for animal protein. Imports constitute a greater part (about $70 \%$ ) of the meat and other livestock products consumed (FAO, 2014). This statistics indicate a huge deficit of local meat production for consumption. Hence, Ghana Government has been making attempts to improve livestock production to reduce the importation.

Despite Ghana Government's efforts to improve small ruminant production in the country by the introduction of Live- stock Development Project (LDP) and other projects between 2005 and 2010, within Ministry of Agriculture MoFA many factors continue to limit the growth of the subsector. Some of these include health, breed related problems (small birth rates, slow growth rates) (Ademosun, 1988), water shortages during the dry season, high mortality and theft of livestock (Anonymous, 2001; Amankwah et al., 2012). Peste des Petits Ruminants (PPR) is considered as the most potentially economically important disease of sheep and goats in the developing world (Anonymous, 2015).

Based on information from stakeholders (local veterinary officials), who often diagnosed the disease using clinical signs, coupled with occasional usage of ELISA and real time PCR when samples were sent to the Central Veterinary Laboratory in Accra, there has been a yearly incidence of PPR in Ghana despite the availability and use of a potent vaccine against PPR. However the disease burden and the impact of vaccination on the prevalence of the disease across the various regions in the country are yet to be documented (Otsyina et al., 2013).

Economic losses caused by PPR could be substantial, however, literature on the disease in Ghana is scanty. This study was, therefore, conducted to investigate the pattern of PPR distribution in Ghana and to assess the impact of vaccination on the disease burden in the country.

\section{MATERIALS AND METHODS}

\section{Study area}

The study was conducted in Ghana which covers an area of 238,539 square kilometers including inland water bodies. It is located on the south central coast of West Africa. The country shares borders in the 
east with Togo, in the north with Burkina Faso, and in the west with Côte d'Ivoire (Nutsukpo et al., 2012). It lies within latitude $4^{\circ} 44^{\prime} \mathrm{N}$ and $11^{\circ} 11^{\prime} \mathrm{N}$; longitudes $3^{\circ}$ $11^{\prime} \mathrm{W}$ and $1^{\circ} 11^{\prime} \mathrm{E}$.

The most important climatic factor influencing vegetation in Ghana is rainfall. The wettest area is in the extreme southwest, where the rainfall is over 2,000 millimeters per year. The driest area is at the southeastern coastal tip, where the rainfall is about 750 millimeters. Agriculture is the backbone of the national economy (Nutsukpo et al., 2012).

The total goat and sheep population in Ghana is estimated respectively at 5,751,000 and 4,156,000 (Anonymous, 2013b). According to the 2010 Population and Housing Census (PHC) report, Ghana's population stood at $24,658,823$ at the time of the 2010 census. The country has ten administrative regions (Ghana Statistical Service, 2013; Fig. 1).

\section{Study design and data collection method}

A retrospective study was conducted using surveillance data on PPR from the period of 2005 to 2013.

Quantitative data on PPR outbreaks for the period of 2005 to 2013 in sheep and goats was extracted from OIE World Animal Health Information System as well as from the Epidemiology Unit of Veterinary Service Directorate (VSD) Accra, Ghana. Data on PPR vaccination records from 2005 to 2013 were also collated from the Veterinary Service Directorate.

\section{Data analysis}

Data was subjected to descriptive analysis using Microsoft Excel v. 2013.

The effect of quarter of the year on PPR outbreak and that of vaccination on PPR outbreak on yearly and regional basis was analysed using ANOVA (Statistical
Package for Social science (SPSS) 16.0) at a level of significance 0.05 .

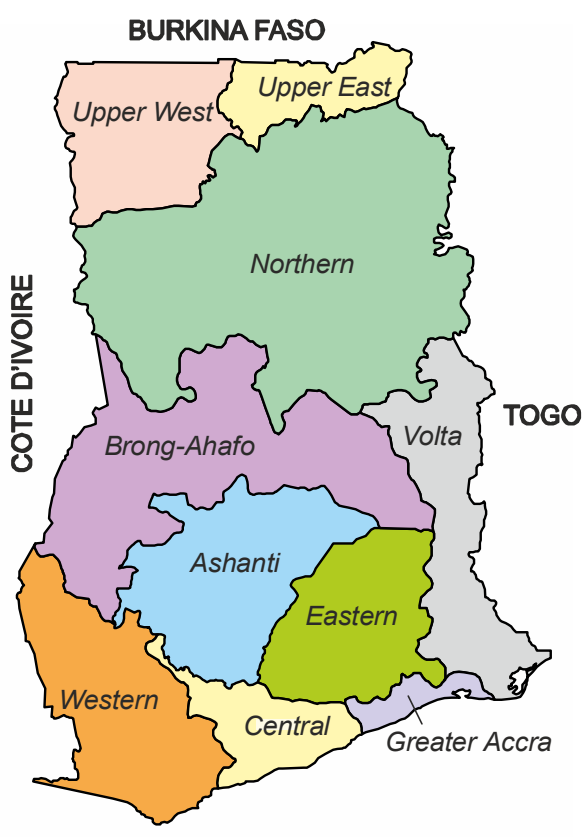

Fig. 1. Map of Ghana showing the ten administrative regions.

\section{RESULTS}

The total number of outbreaks for the period of study was 678 while the total number of small ruminants in Ghana was 9907 thousand as specified by FAO (2013); hence the prevalence of PPR in Ghana from 2005 to 2013 was $6.84 \%$ (678/9907) per thousand small ruminant population. The highest number of outbreaks of PPR occurred in 2011, followed by 2012 and 2010 .

From 2010 to 2012, most PPR outbreaks occurred mostly in the first quarter of each year (from January to March) which is the peak of the dry season, followed by the second quarter which was the early raining season (Table 1). 
Table 1. Distribution of PPR outbreaks by quarter of the year

\begin{tabular}{lc}
\hline Quarter & Outbreak \\
\hline $1^{\text {st }}($ Jan-Mar) & 225 \\
$2^{\text {nd }}($ Apr-Jun) & 195 \\
$3^{\text {rd }}($ Jul-Sept $)$ & 127 \\
$4^{\text {th }}$ (Oct-Dec) & 131 \\
\hline Total & 678 \\
\hline
\end{tabular}

Table 2. Distribution of PPR outbreaks and number of vaccinations according to years

\begin{tabular}{ccc}
\hline Year & Outbreaks & Vaccinations \\
\hline 2005 & $17^{\mathrm{c}}$ & $244,368^{\mathrm{bc}}$ \\
2006 & $29^{\mathrm{bc}}$ & $224,938^{\mathrm{bc}}$ \\
2007 & $8^{\mathrm{d}}$ & $313,954^{\mathrm{b}}$ \\
2008 & $31^{\mathrm{bc}}$ & $118,954^{\mathrm{d}}$ \\
2009 & $63^{\mathrm{b}}$ & $312,580^{\mathrm{b}}$ \\
2010 & $143^{\mathrm{a}}$ & $37,889^{\mathrm{b}}$ \\
2011 & $177^{\mathrm{a}}$ & $892,115^{\mathrm{a}}$ \\
2012 & $150^{\mathrm{a}}$ & $109,715^{\mathrm{d}}$ \\
2013 & $60^{\mathrm{b}}$ & $210,260^{\mathrm{bc}}$ \\
\hline Total & 678 & $2,805,415$ \\
\hline
\end{tabular}

different superscripts within a column indicate statistically significant difference at $\mathrm{P}<0.05$.

Table 3. Distribution of PPR outbreaks and vaccinations according to the region

\begin{tabular}{llc}
\hline Regions & $\begin{array}{l}\text { Out- } \\
\text { breaks }\end{array}$ & Vaccinations \\
\hline Greater Accra & $1^{\mathrm{e}}$ & $1,992,260^{\mathrm{c}}$ \\
Ashanti & $74^{\mathrm{c}}$ & $259,188^{\mathrm{bc}}$ \\
Brong-Ahafo & $28^{\mathrm{e}}$ & $234,845^{\mathrm{bc}}$ \\
Central & $114^{\mathrm{b}}$ & $271,684^{\mathrm{b}}$ \\
Eastern & $127^{\mathrm{b}}$ & $291,994^{\mathrm{b}}$ \\
Volta & $45^{\mathrm{d}}$ & $502,401^{\mathrm{a}}$ \\
Western & $190^{\mathrm{a}}$ & $130,714^{\mathrm{d}}$ \\
Northern & $37^{\mathrm{d}}$ & $470,319^{\mathrm{ab}}$ \\
Upper east & $49^{\mathrm{d}}$ & $178,894^{\mathrm{c}}$ \\
Upper west & $13^{\mathrm{e}}$ & $13^{\mathrm{e}}$ \\
\hline Total & 678 & $4,596,275$ \\
\hline
\end{tabular}

different superscripts within a column indicate statistically significant difference at $\mathrm{P}<0.05$.
All regions reported PPR outbreaks, most numerous in the Western Region, followed by Eastern and Central regions (Table 3) while PPR vaccinations also covered all regions with Western region having the lowest number of animals vaccinated and Volta region the highest.

Comparing outbreak distributions with vaccination pattern, vaccination impacted positively on the trend of PPR outbreaks in 2007 and in 2013 (Table 2).

There was no significant influence $(\mathrm{P}=0.608)$ on quarterly distribution of PPR outbreaks (Table 1) while significant effects of vaccination on the PPR outbreak pattern both at yearly distribution $(\mathrm{P}=0.0102$; Table 2$)$ and regional distribution $(\mathrm{P}=0.0166$; Table 3$)$ were established.

\section{DISCUSSION}

The prevalence of PPR in Ghana from 2005 to 2013 was $6.84 \%(678 / 9,907)$ per thousand small rumianant population. The areas with the highest number of outbreaks are mostly the coastal areas which could be due to the unrestricted movement of small ruminants from neighbouring countries such as Côte D'Ivoire which are noted to be endemic in PPR as reported by Kaukarbayevich (2009) and Abubakar et al., (2011) who concluded that control of PPRV may be attained using measures including movement control, quarantine of infected animals, removal of potentially infected fomites and restriction on the importation of sheep and goats from infected areas.

From 2009 to 2010, PPR cases occurred mostly in first and second quarters which agreed with the findings of Hegde et al. (2009) demonstrating that incidences of PPR were the highest during the rainy season and in the dry agro-climatic 
zones. The authors suggested that the density and environmental factors contributed to disease incidence, which they explained by the sudden onset of the rainy season in the middle of June and huddling together of animals enhancing close contact $-\mathrm{a}$ major transmission route for PPR.

From 2010 to 2012, most cases occurred from January to March which conforms to findings of Okoli (2003) and Hedge et al. (2009) demonstrating peaks in PPR outbreaks in February, during the cold dry season to the dusty winds during the harmattan season as risk factors for respiratory tract infections since excessive dust easily irritates the upper respiratory tract, rendering exposed goats more susceptible to the disease. Poor nutrition due to deficiency of fodder during that period (Wosu et al., 1994) also contributed to the findings. Other workers also established that PPR epidemics tend to occur during the rainy season when goats are herded together and around Christmas when movement to markets increases (Nawathe, 1984; Muse et al., 2012; Salih et al., 2014). The highest outbreaks of PPR occurred in 2011, followed by 2012 and 2010 (Table 2). The surge in PPR outbreaks in 2011 could be due to the shortage of PPR vaccines that was experienced in the country between 2010 and 2011 and its effect spilled over into 2012.

Vaccination had a positive impact on the trend of PPR outbreaks in 2007 and in 2013. This could be due to the free PPR vaccination campaign which saw high patronage in 2006 and the highly subsidised PPR vaccination campaign in 2013 that was part of the pilot project of the vaccine approach strategy of reducing PPR in the West African Sub-Region (OIE, 2013). This showed that prompt yearly and subsidised vaccination of goats will help to reduce the outbreak of PPR especially during the critical periods of the year. Although the distribution by species could not be attempted because the data set only provided aggregated data on small ruminants, however absolute figures were used for analysis at the regional level because baseline data in terms of animal population figures at the regional levels were not available.

In conclusion, PPR is endemic in Ghana with peaks in both the rainy and dry seasons, but mostly in the dry season. Vaccination of animals against PPR has a positive impact on the outbreak of PPR in the country. It is therefore recommended that PPR vaccines should be readily available as vaccination campaigns positively impact on PPR outbreak. There should be harmonisation of PPR vaccination calendar across the various regions such that the vaccination is carried out at the same period throughout the country. Restriction on movement of animals form high risk areas should be enforced. Subregional mass vaccination programmes could be introduced for PPR as was done for Rinderpest and further studies to be embarked to establish the possible predisposing factors of PPR in the country.

\section{REFERENCES}

Abubakar, M., S. Ashiq, A. Zahoor, M. J. Arshed \& A. C. Banyard, 2011. Diagnosis and control strategies for peste des petits ruminants virus: Global and Pakistan perspectives. Pakistan Veterinary Journal, 31, 267-274.

Ademosun, A. A., 1988. Trends in small ruminant production for the last two decades and its future in West and Central Africa. In: Proceedings of the Workshop for the Improvement of Small Ruminants in West and Central Africa, 21-25 November 1988, Ibadan, Nigeria, pp. 18-22. 
Amankwah, K., L. Klerkx, S. J. Oosting, O. Sakyi-Dawson, A. J. Van der Zijpp \& D. Millar, 2012. Diagnosing constraints to market participation of small ruminant producers in Northern Ghana: An innovation systems analysis. NJAS Wageningen Journal of Life Sciences, 60-63, 37-47.

Anonymous, 1999. Recognizing Peste des Petits Ruminants. A Field Manual. http://www.fao.org/docrep/003/x1703e/x1 703e00.HTM (Date last accessed 25 January 2016).

Anonymous, 2001. African Development Fund ADF; Appraisal Report Livestock Development Project, Republic of Ghana, http://www.afdb.org/fileadmin/uploads/afd b/Documents/Project-and-Operations/GH2001-108-en-adf-bd-wp-ghana-ar-livestock-development.pdfpp 8-11 (Date last accessed 13 January 2016).

Anonymous, 2011. Peste des Petits Ruminants. Center for food security and public health, Iowa state university, http://www.cfsph.iastate.edu/DiseaseInfo/n otes/PestedesPetitsRuminants.pdf (Date last accessed 25 January 2016).

Anonymous, 2013a. FAO Statistical Yearbook. World Food and Agriculture. www.fao.org/docrep/018/i3107e/i3107e.P DF (Date last accessed 25 January 2016).

Anonymous, 2013b. Ghana - Ghana Agricultural Production Survey (minor season) 2013, second round. GHA-MoFA-SRIDGAPS-2013-V1.0, http//www.statsghana. gov.gh.

Anonymous, 2015. The State of Food Insecurity in the World, http://foodsecurity index.eiu.com/.www.fao.org/3/a-i4030e.pdf (Date last accessed 25 January 2016).

Bailey, D., A. Banyard, P. Dash, A. Ozkul \& T. Barrett, 2005. Full genome sequence of peste des petits ruminant virus, a member of Morbillivirus genus. Virus Research, 110, 119-124.

Emikpe, B. O. \& S. O. Akpavie, 2011. The clinicopathologic effects of Peste des petits ruminants virus infection in West African dwarf goats. Small Ruminant Research, 95, 168-173.

FAO, 2014. Poultry Sector Ghana. FAO Animal Production and Health Livestock Country Reviews. No. 6 Rome. www.fao. org/3/a-13663e.pdf (Date last accessed 13 January 2016).

Ghana Statistical Service, 2013. Ghana Statistical Service Report, http://www.statsghana. gov.gh.

Hegde, R., A. R. Gomes, H. K. Muniyellappa, S. M. P. Byregowda, \& C. Giridhar Renukaprasad, 2009. A short note on peste des petits ruminants in Karnataka, India. Revue Scientifique et Technique de l'Office International des Epizooties, 28, 1031-1035.

ILRI, 1980. Peste des Petits Ruminants (PPR) in Sheep and Goats: Proceedings of an International Workshop, Ibadan, Nigeria, pp. 24-26.

Kaukarbayevich, K. Z., 2009. Epizootological analysis of PPR spread on African continent and in Asian countries. African Journal of Agricultural Research, 4, 787-790.

Ministry of Food and Agriculture, 2013. Pilot Program Based Budget for 2013-2015, http://www.mofep.gov.gh/sites/default/file $\mathrm{s} / \mathrm{pbb} / 1 \% 20$ GHANA $\% 20$ MINISTRY\%20 OF\%20FOOD\%20AND\%20AGRICULT URE\%202013.pdf (Date last accessed 13 January 2016).

Munir, M., 2014. The role of wild small ruminants in the epidemiology of peste des petitis ruminants. Transboundary and Emerging Diseases, 61, 411-424.

Muse, E. A., E. D. Karimuribo, G. C. Gitao, G. Misinzo, L. S. B. Mellau, P. L. M. Msoffe, S. E. Swai \& O. Albano, 2012. Epidemiological investigation into the introduction and factors for spread of Peste des Petits Ruminants, southern Tanzania. Onderstepoort Journal of Veterinary Research, 79, 457-461.

Nawathe, D. R., 1984. The control of peste des petits ruminants in Nigeria. Preventive Veterinary Medicine, 2, 147-155.

Nutsukpo, D. K., A. Jalloh, R. Zougmoré, G. C. Nelson \& S. T. Thomas. 2012. West 
African agriculture and climate change: Ghana. In: West African Agriculture and Climate Change: A Comprehensive Analysis, ed A. Jalloh, International Food Policy Research Institute (IFPRI). pp. 141-172.

OIE, 2013. Launch meeting for the project "Vaccine Standards and Pilot Approach to Peste des Petits Ruminants (PPR) Control in Africa", Addis Ababa, http://www. oie.int/for-the-media/press-releases/detail/ article/launch-meeting-for-the-project-vaccine-standards-and-pilot-approach-to-peste-des-petits-ruminants (Date last accessed 25 January 2016).

OIE, 2015. Global strategy for the control and eradication of PPR. www.oie.int/eng/ PPR2015/doc/PPR-Global-Strategy-201503-28.pdf (Date last accessed 25 January 2016).

Okoli, I. C., 2003. Incidence and modulating effects of environmental factors on trypanosomosis, peste des petits ruminants (PPR) and bronchopneumonia of West African dwarf goats in Imo state, Nigeria. Livestock Research for Rural Development, 15, article \#67, http://www.lrrd. org/lrrd15/9/okoli159.htm (Date last accessed 25 January 2016).

Otsyina, H. R., C. T. Arthur, M. AyimAkunnor \& F. Y. Obese, 2013. Sero-prevalence of Peste des Petits Ruminants (PPR) in sheep, goats and cattle in Ghana. Bulletin of Animal Health and Production in Africa, 61, 473-479.

Salih, H. A. M., A. A. M. Elfadil, I. K. Saeed \& Y. H. Ali, 2014. Seroprevalence and risk factors of Peste des Petits Ruminants in sheep and goats in Sudan. Journal of
Advanced Veterinary and Animal Research, 1, 42-49.

Scott, G. R., 1981. Rinderpest and peste des petits ruminants. In: Virus Diseases of Food Animals, vol. 2, ed E. P. J. Gibbs, Academic Press, London, UK, pp. 401432.

Tuah, A. K., M. K. Buadu, F. Y. Obese \& K. Brew, 1989. The performance, potentials and limitations of the West African Dwarf goat for meat production in the forest belt of Ghana. http://www.fao.org/wairdocs/ ilri/x5520b/x5520b18.htm (Date last accessed 25 January 2016).

Wosu, L. O., J. E. Okiri \& P. A. Enwezor, 1990. Optimal time for vaccination against peste des petits ruminants (PPR) disease in goats in the humid tropical zone in southern Nigeria. Archives Roumaines de Pathologie Experimentales et de Microbiologie, 49, 283-291.

Paper received 23.09.2015; accepted for publication 12.11.2015

\section{Correspondence:}

B. O. Emikpe

Department of Pathobiology,

School of Veterinary Medicine,

Kwame Nkrumah University of Science and

Technology,

Kumasi, Ghana.

mobile phone: +2348066486080 ,

$+233549410841$

e-mail: banabis2001@yahoo.com 